\title{
Shares rebound at scent of draft sequence
}

\section{Paul Smaglik, Washington}

The world's scientific community may still have to wait a few more days for the news widely expected early next week - that the draft sequence of the human genome has been completed. But shares in genomics companies have already been rising steadily for several weeks in anticipation.

These shares have been through a rollercoaster ride in the past six months. They began to climb steadily last December, immediately before the announcement that human chromosome 22 had been sequenced. After that milestone, prices were propelled further upwards by word that both the publicly funded Human Genome Project (HGP) and its commercial counterpart Celera Genomics of Rockville, Maryland, were speeding through the human gene sequence (see Nature 403, 119; 2000).

But the bubble burst in early March, and the decline gathered pace when US President Bill Clinton and British Prime Minister Tony Blair issued a joint statement that genomic information should be freely available. This was widely interpreted by investors as an attack on companies that intended to patent genes, and contributed directly to the second-biggest drop in the history of NASDAQ (see Nature 404, 424; 2000).

It is likely to be a long time before the peak values are regained. But anticipation of the impending sequencing announcement seems to have repaired some of the damage. For example, the value of a Celera share plummeted from $\$ 276$ at the beginning of March to $\$ 122.5$ immediately after the Clinton/Blair announcement.

Celera's shares continued to slide, hovering around the $\$ 70$ mark until early June. Now that both Celera and the HGP are due to announce that they have drafts of the human genome in hand, the price has climbed back above $\$ 100$ a share (see figure).

Shares in Incyte Genomics of Palo Alto, California, were trading on Monday at around $\$ 92$, after dipping to under $\$ 50$ following the announcement. The restoration in the fortunes of Human Genome Sciences of Rockville, Maryland, has been even more dramatic; its shares, which fell from a peak of $\$ 232$ to just above $\$ 50$ a share following the Clinton/Blair statement, are now back to around $\$ 135$ a share.

"The stocks are probably still less than half of the highs of earlier in the year, but they've certainly rebounded from the lows," says Winton Gibbons, an analyst from William Blair \& Co. in Chicago.

Gibbons attributes some of the rebound to anticipation over the next stage of the genome project, but says that other factors may also be at work. For example, he says, investors soon realized that the Clinton/Blair

NASDAQ Biotech index Celera Genomics Inc.

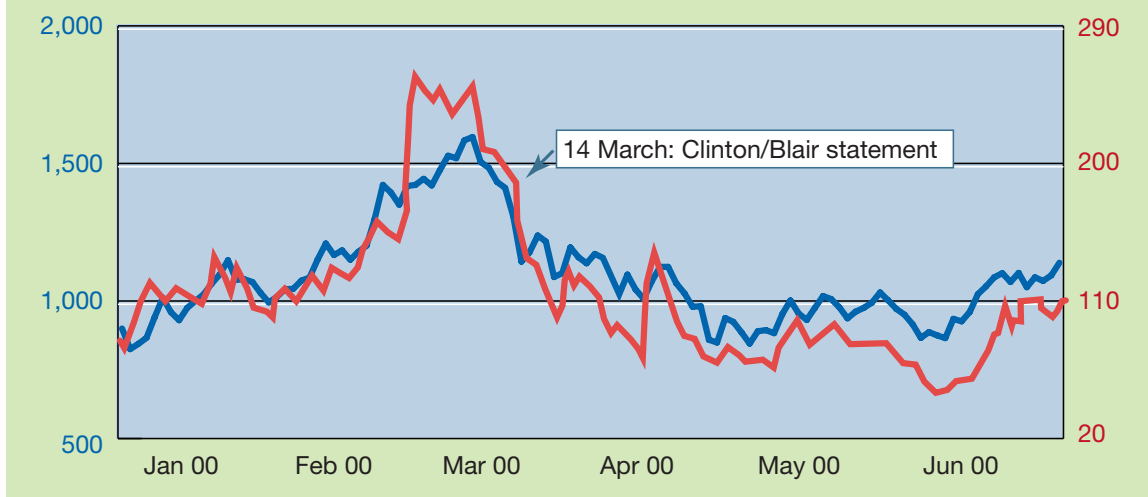

Bouncing back: share prices are on their way up again.

statement was relatively toothless. Guidelines issued by the US Patent and Trademark Office showed that the government wasn't going to restrict gene patenting as much as some people had believed.

Gibbons expects the rebound to benefit 'next-generation' companies as well. For example, news of plans being made to sequence the genomes of other organisms, such as mice, will help functional genomics companies, which analyse animal genes that have human homologues.

The March panic sell-off was a blessing for bargain hunters, says David Molowa, an analyst with Chase H\&Q in New York. The aftermath resulted in a 'fire sale', Molowa believes. "Folks with a little bit of guts stormed in and started reversing the trend."

Both Molowa and Eric Schmidt, an analyst with SG Cowen Securities in New York, predict that there will now be a period of consolidation, with large companies buying smaller, specialized ones. "There are too many genomics companies with too narrow a piece of the pie," says Schmidt.

If genomics companies are to maintain or increase their value, they will have to find a way to make money beyond the stock market. All have different approaches. The HGP is becoming a conventional biotech company to develop drugs, while Celera is sticking to its database subscription model. Until companies turn a profit, it will be hard to assess their true value, Schmidt concludes.

\section{GM food 'dumped on India as aid'}

\section{K. S. Jayaraman, New Delhi}

A Delhi-based environmentalist group has accused the United States of 'dumping' genetically modified (GM) soya and corn on India in the form of food aid "in a bid to create an artificial market and keep the tottering genetic-engineering giants afloat".

The United States began sending food to Orissa in November 1999. The US Agency for International Development does not deny that it supplies GM food in aid packages, saying that it does not distinguish between GM and non-GM food.

Vandana Shiva, president of the Research Foundation for Science, Technology and Ecology (RFSTE), says that the \$4.2 million US food aid sent to cyclone victims in the state of Orissa last October contained genetically modified forms of soy beans and corn rejected by traditional markets in Europe and Japan.

The discovery was revealed by test reports from Genetic ID, an American company that tests for GM organisms in food. The company tested samples of food that had been collected from Orissa and sent for analysis by RFSTE, and concluded that "significant levels of genetically modified DNA were detected in the samples".

India has no policy on GM foods at present. The secretary of the Department of Biotechnology, Manju Sharma, says that the department is still "in the process of finalizing" the policy in consultation with the ministries of health, the environment, food and agriculture.

Shiva complains that, in the absence of policy and test facilities, India has become an illegal dumping ground for unwanted GM foods. She claims that the US government "used the money intended for relief to the poor to subsidize the biotech industry, in order to create market entry for GM products”. 